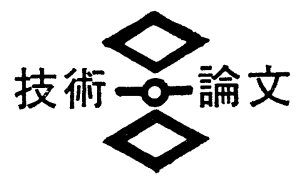

$$
\begin{aligned}
& \text { ロータリーキルンによる } \\
& \text { パームカーネルシェル活性炭の }
\end{aligned}
$$

製造研究

-1981.11 .20 受理一

\begin{abstract}
大平洋金属(物) 廣瀬正巳*，川和田邦男**，毒木宏之**
日 本大学 柳井 弘***
\end{abstract}

\section{1. 緒言}

活性炭製造用の原料は，工業的には活性化の難易， 品質, 価格, 大量に入手可能かぞらかなどの墸点が選 定の基準になる。筆者らは, 既報のようにインドネシ アの豊富なゴム樹廃材を出発原料としてロータリーキ ルンおよびシャフト炉による水蒸気賦活試験を行い, 液相用粉末活性炭の工業化に成功した ${ }^{122) 。 そ こ て ゙, さ ~}$ らにマレイシアおよびインドネシアなどのパーム推油 工場で発生し, 有効利用されていないパームカーネル シェルを炭化・賦活して粒状活性炭を製造することに 着目した。

このパームカーネルシェル炭（以下パーム炭と称す る）を出発原料とした破砕活性炭の製造プロセスは, まだ世界のいずこでも実施されていないので, 最初に 炉内燃垶式ロータリーキルン (以下直熱式ロータリー キルンと称する）を使用して原料木炭の構造和よび灰 分組成がガス賦活反応におよぼす影響を調べた。この 試験では，パーム炭のほかに比較のためヤシ殼炭，ゴ ム樹炭拉よびパルプ用チップ炭を，それぞれ加熱ガス と並流させる方式で水蒸気賦活した結果, ポロシティ が最も小さく緻密な構造をもち，から灰分中のシリカ 含有量が多く, 塩基性物質含有量の少ないパーム炭は ガス賦活反応が最も遅いことが確認された ${ }^{8)}$ 。

そこで，この試験結果に基づいて新ロータリーキル ン（以下熱風式ロータリーキルンと称する）を設置し てパーム炭の賦活試験を実施し, 比較的賦活しにくい パーム炭から粒状パームカーネルシェル活性岸（以下 パーム活性炭と称する) を工業的製造するプロセス を開発したので，その試験結果を報告する。

* 技術開発部 東京都千代田区大手町 1-6-1

** 新潟工場 新潟市太郎代山边

*** 理工学部講師 東京都千代田区神田駿河台

\section{2. 試験装置および方法}

2.1 水蒸気賦活装置および試験法

2.1 .1 直熱式ロータリーキルン

試験に用いた直熱式ロータリーキルンは，Fig. 1 に 示すように 2 点支持の並流加熱式で, キルン本体は外 径 $0.7 \mathrm{~m} \phi$ (内径 $0.57 \mathrm{~m} \phi$ ), 長さ $12 \mathrm{~m}$, 傾斜角 $2 / 100 \sim$ $4 / 100$ (可変), 回転数 $0.3 \sim 3.0 \mathrm{rpm}$ であり, 水蒸気は 炉前から $7 \mathrm{~kg} / \mathrm{cm}^{2}$ (ボイラー圧力) で吹込んだ。バーナ 一はガス専燒型でメインバーナーのほかに, キルンの 長さ方向のほぼ中央にサイドバーナーを設置して, キ ルン中央部の賦活温度 $\left(\mathrm{T}_{3}\right)$ を炉内入口温度 $\left(\mathrm{T}_{1}\right)$ まで 上昇できるようにした。またキルン内部には耐熱鋳鋼 製の掻上板を 2 列配置した。

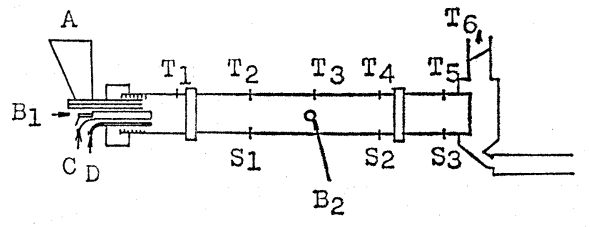

A : Charcoal, $B_{\mathbf{1}}$ : Natural gas (Main Burner) $\mathrm{B}_{2}$ : Natural Gas (Side Burner)

C : Air D : Steam

$T_{n}$ : Thermocouple $S_{n}$ : Sampling Hole

Fig. 1 Inner fired rotary kiln

本試験では, 水蒸気賦活の難易性を比較するために 5〜32meshに整粒したパーム炭のほかにヤシ殼炭も使 用した。パーム炭の賦活では水蒸気送入速度と給炭速 度を変化させ，ヤシ殼炭の場合には賦活温度 $\left(\mathrm{T}_{3}\right)$ を 変化させ, これらの条件が生成活性炭のメチレンブル 一脱色力, 賦活収率および硬度に和よぼす影響を調べ 
た。

\section{1 .2 熱風式ロータリーキルン}

熱風式ロータリーキルンは, Fig. 2 亿示すように直 熱式之同様に 2 点支持の並流加熱式で外径 $1.0 \mathrm{~m} \phi$ (内 径 $0.6 \mathrm{~m} \phi)$, 長さ $12 \mathrm{~m}$, 傾斜角 $1 / 100$, 回転数 $0.3 \sim 3.0$ rpmである。

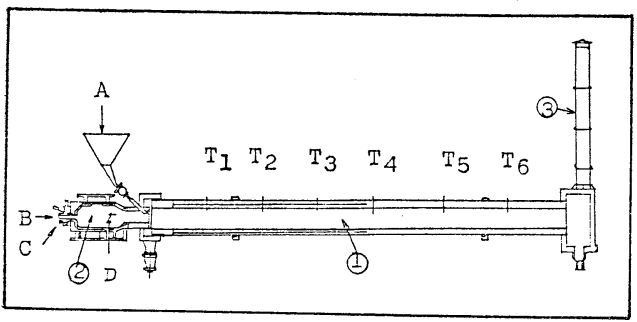

(1) : Rotary Kiln (2): Combustion Chamber

(3) : Chimney

A : Charcoal

C : Air

B : Natural Gas

$T_{\mathrm{n}}$ : Thermocouple

Fig. 2 Rotary kiln with combustion chamber

Table 1 Proximate analysis of charcoal

\begin{tabular}{lccc}
\hline \multicolumn{1}{c}{ Charcoal } & $\begin{array}{c}\text { Fixed Carbon } \\
(\%)\end{array}$ & $\begin{array}{c}\text { Volatile Matter } \\
(\%)\end{array}$ & $\begin{array}{c}\text { Ash } \\
(\%)\end{array}$ \\
\hline *Palm Charcoal & 79.71 & 14.99 & 5.30 \\
Coconut Shell Charcoal & 83.60 & 14.94 & 1.46 \\
\hline
\end{tabular}

*Palm Charcoal : Palm Kernel Shell Charcoal 本試験では，パーム炭を5〜12，12３2mesh破碎 ・整粒したのち，それぞれについて賦活試験を実施し た。すなうち，5１2mesh整粒炭の試験では賦活温度 $\left(\mathrm{T}_{3}\right)$ と天然ガス燃焼時の空燃比を, 12〜32mesh 整粒 炭では炉内滞留時間をそれぞれ变化させ，これらの条 件が生成活性炭のメチンンブルー脱色力, 賦活収率お よび硬度におよ汸す影響を調べた。

\section{2 原料括よび分析法}

\section{2 .1 原料の性状}

供試原料木炭の工業分析結果を Table 1 亿，またそ の粒度分布をTable 2 に示した。

\section{2 .2 分析法}

生成活性炭の性能は, JISK1470-1967によってメチ レンブルー脱色力を，JISK1412-1958によってベンゼ ン吸着力を，JISK1474-1975によって硬度をそれぞれ 測定した。なお，この一連の賦活試験を通じて吸着性 能の尺度としてメチンンブルー脱色力を測定して比較 した。

\section{3. 結果および考察}

3.1 直熱式ロータリーキルンによる試験結果

炉内滞留時間 $4 \mathrm{hr}$, 炉内入口温度 $\left(\mathrm{T}_{1}\right)$ $880^{\circ} \mathrm{C}$, 賦活温度 $\left(\mathrm{T}_{3}\right) 950^{\circ} \mathrm{C}$ 之注济一定に 乙, 水蒸気送入速度と給炭速度を変化さ せて5〜32meshのパーム炭を水蒸気賦活 した試験結果の一例をTable 3 に示し た。

この表から明らかなように, 水蒸気送

Table 2 Screen analysis of charcoal $(\%)$

\begin{tabular}{lcccccccc}
\hline \multicolumn{1}{c}{ Charcoal } & $\begin{array}{c}5-6 \\
\text { mesh }\end{array}$ & $\begin{array}{c}6-9 \\
\text { mesh }\end{array}$ & $\begin{array}{c}9-12 \\
\text { mesh }\end{array}$ & $\begin{array}{c}12-16 \\
\text { mesh }\end{array}$ & $\begin{array}{c}16-20 \\
\text { mesh }\end{array}$ & $\begin{array}{c}20-24 \\
\text { mesh }\end{array}$ & $\begin{array}{c}24-32 \\
\text { mesh }\end{array}$ & $\begin{array}{c}-32 \\
\text { mesh }\end{array}$ \\
\hline Palm Charcoal & 7.8 & 48.3 & 20.7 & 12.3 & 6.9 & 2.9 & 0.9 & 0.2 \\
Coconut Shell Charcoal & 5.4 & 41.8 & 25.7 & 12.5 & 8.1 & 5.0 & 0.9 & 0.6 \\
\hline
\end{tabular}

Table 3 Effects of steam rate and charging rate on the activation

(5-32 mesh palm charcoal)

\begin{tabular}{|c|c|c|c|c|c|c|c|}
\hline $\begin{array}{l}\text { Charging } \\
\text { Rate } \\
\mathrm{kg} / \mathrm{hr}\end{array}$ & $\begin{array}{l}\text { Steam } \\
\text { Rate } \\
\mathrm{kg} / \mathrm{hr}\end{array}$ & $\begin{array}{l}\text { Retention } \\
\text { Time } \\
\quad \text { hr }\end{array}$ & 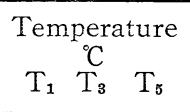 & $\begin{array}{l}\text { Methylene Blue } \\
\text { Adsorbed } \\
\text { m } \ell / g\end{array}$ & $\begin{array}{l}\text { Hardness } \\
6-12 \\
\text { mesh }\end{array}$ & $\begin{array}{l}(\%) \\
12-32 \\
\text { mesh }\end{array}$ & $\begin{array}{c}\text { Yield } \\
\%\end{array}$ \\
\hline 28.4 & 90 & 4 & 880950860 & 119 & 84.3 & 98.0 & 49.9 \\
\hline 28.6 & 80 & 4 & $880948 \quad 842$ & 108 & 87.9 & 98.0 & 55.0 \\
\hline 27.7 & 70 & 4 & 880950835 & 99 & 88.9 & 98.3 & 57.9 \\
\hline 27.7 & 70 & 4 & 880950725 & 99 & 88.9 & 98.3 & 57.9 \\
\hline 32.5 & 80 & 4 & 880950755 & 105 & 89.3 & 99.0 & 56.3 \\
\hline 36.4 & 90 & 4 & 880949777 & 107 & 87.3 & 97.2 & 52.4 \\
\hline
\end{tabular}


入速度を増すと生成活性炭の賦活収率および硬度は低 下しメチレンブルー脱色力は向上した。また，水蒸気 送入速度と給炭速度との比を湾 2.5 とし, 約 $30 \sim 40$ $\mathrm{kg} / \mathrm{hr}$ (wet) の範团で給炭速度を増大させると, 生成 活性炭のメチレンブルー脱色力が若干向上乙賦活収率 が若干低下したが，硬度は添とんぞ変化しなかった。

ヤシ殼炭は，前述のと和りロータリーキルンによる 木質系原料の予備賦活試験結果からパーム炭よりも賦 活しやすいことが判明していたので，本試験ではその 炉内滞留時間をパーム炭の場合より $1 \mathrm{hr}$ 短くして $3 \mathrm{hr}$ とした。賦活温度 $\left(T_{3}\right)$ はサドバーナーを調節してパ 一ム炭の場合よりもいくぶん低く $860,890,930^{\circ} \mathrm{C}$ と 変化させた。その試験結果をTable 4 亿示した。すな わち, パーム炭の賦活の場合と同様に賦活温度 $\left(\mathrm{T}_{3}\right)$ を 高くすると生成活性炭の吸着性能は向上した。賦活温 度 $\left(T_{3}\right)$ \% $930^{\circ} \mathrm{C}$ とたとき，これまでパーム炭の直熱 式ロータリーキルンによる賦活試験では得られなかっ たメチレンブルー脱色力 $160 \mathrm{~m} \ell / \mathrm{g}$ の活性炭を製造す ることができた。

\section{2 熱風式ロータリーキルンによる試験結果}

これまでの直熱式ロータリーキルンによる水蒸気賦 活では, パーム炭がガス賦活反応しにくいため吸着性 能の高いパーム活性炭を製造するのは困難であること が判った。そこで，前述のように熱風式ロータリーキ
ルンを新設してパーム炭の忓内滞留時間を長くし, キ ルン内需团気の調整を容易にし,さらにパーム炭の粒 度範囲を狭くしてあらかじめ5１2，12３2mesh節 分けて，それぞれについて賦活試験を実施した。

5〜12mesh のパーム炭について, 給炭速度 $35 \mathrm{~kg} / \mathrm{hr}$ (wet), 师内滞留時間 $10 \mathrm{hr}$, 水蒸気送入速度 $100 \mathrm{~kg} / \mathrm{hr}$ を活济一定として，賦活温度 $\left(\mathrm{T}_{3}\right)$ を $950,920,880^{\circ} \mathrm{C}$ と

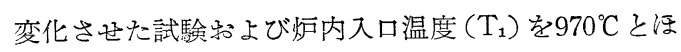
涩一定として空然比を $12.5 ， 11.5 ， 10.8 ， 9.6$ と変化 させた試験結果をTable 5 亿示した。

Table 5 から, 給炭速度約 $35 \mathrm{~kg} / \mathrm{hr}$ (wet), 水蒸気 送入速度 $100 \mathrm{~kg} / \mathrm{hr}$, 炉内滞留時間 $10 \mathrm{hr}$, 炉内入口温 度 $\left(T_{1}\right) 970^{\circ} \mathrm{C}$, 空然比 11 の条件で5 12mesh 整粒炭を 水蒸気賦活することによってメチレンブルー脱色力 130 150m / / g の活性炭を製造できることが判った。 な拉，忓内入口温度 $\left(\mathrm{T}_{1}\right)$ を $1,000^{\circ} \mathrm{C}$ に上げた場合に は, メチレンブルー脱色力 $180 \mathrm{~m} \ell / \mathrm{g}$ の活性炭を製造 することができた。

12〜32meshのパーム炭について, 給炭速度約 $50 \mathrm{~kg} /$ $\mathrm{hr}$ (wet), 水蒸気送入速度 $120 \mathrm{~kg} / \mathrm{hr}$, 师内入口温度 $\left(\mathrm{T}_{1}\right) 1,000^{\circ} \mathrm{C}$, 空然比 11 とほぼ一定にして, 炉内滞留 時間を $10,8.3,6.7 \mathrm{hr}$ と変化させて賦活試験を実施し た結果をTable 6 亿示した。

これによると，忓内滞留時間が10hr の場合に生成活

\section{Table 4 Effects of furnace temperature on the activation of coconut charcoal}

(5-32 mesh coconut charcoal)

\begin{tabular}{|c|c|c|c|c|c|c|c|c|}
\hline $\begin{array}{l}\text { Charging } \\
\text { Rate } \\
\text { kg/hr }\end{array}$ & $\begin{array}{l}\text { Steam } \\
\text { Rate } \\
\mathrm{kg} / \mathrm{hr}\end{array}$ & $\begin{array}{l}\text { Retention } \\
\text { Time } \\
\qquad \text { hr }\end{array}$ & 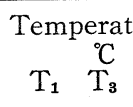 & & $\begin{array}{c}\text { Methylene Blue } \\
\text { Adsorbed } \\
\text { m } \ell / \mathrm{g}\end{array}$ & $\begin{array}{l}\text { Hardness } \\
6-12 \\
\text { mesh }\end{array}$ & $\begin{array}{l}(\%) \\
12-32 \\
\text { mesh }\end{array}$ & $\begin{array}{l}\text { Yield } \\
\%\end{array}$ \\
\hline 33.2 & 87.0 & 3 & 860860 & 642 & 100 & 84.0 & 97.0 & 52.4 \\
\hline 34.9 & 95.0 & 3 & 870890 & 680 & 115 & 83.8 & 96.4 & 54.6 \\
\hline 36.1 & 96.5 & 3 & 870928 & 721 & 160 & 75.0 & 95.1 & 41.5 \\
\hline
\end{tabular}

Table 5 Steam activation test of 5-12 mesh palm charcoal

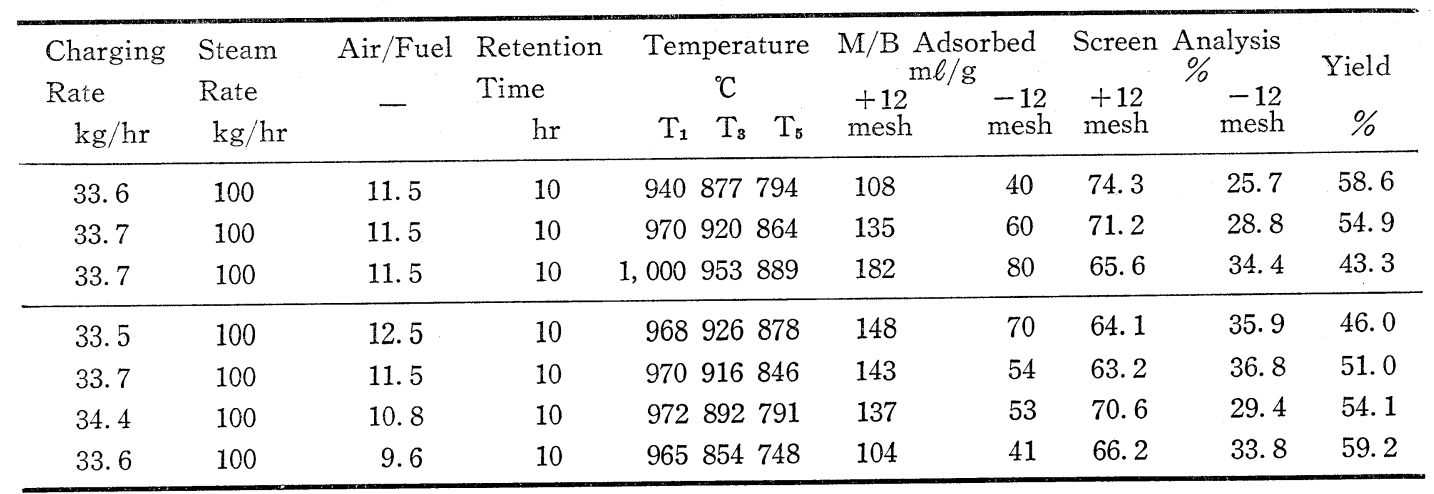


Table 6 Steam activation test of 12-32 mesh palm charcoal

\begin{tabular}{|c|c|c|c|c|c|c|c|c|c|c|c|}
\hline \multirow{2}{*}{$\begin{array}{l}\text { Charging } \\
\text { Rate } \\
\quad \mathrm{kg} / \mathrm{hr}\end{array}$} & \multirow{2}{*}{$\begin{array}{l}\text { Steam } \\
\text { Rate } \\
\mathrm{kg} / \mathrm{hr}\end{array}$} & \multirow{2}{*}{$\begin{array}{c}\text { Air/Fuel } \\
-\end{array}$} & \multirow{2}{*}{$\begin{array}{l}\text { Retention } \\
\text { Time } \\
\qquad h r\end{array}$} & \multirow{2}{*}{\multicolumn{3}{|c|}{$\begin{array}{c}\text { Temperature } \\
{ }^{\circ} \mathrm{C}\end{array}$}} & \multicolumn{2}{|c|}{$\begin{array}{l}\mathrm{M} / \mathrm{B} \text { Adsorbed } \\
\mathrm{m} \ell / \mathrm{g}\end{array}$} & \multicolumn{2}{|c|}{ Screen Analysis } & \multirow{2}{*}{$\begin{array}{c}\text { Yield } \\
\%\end{array}$} \\
\hline & & & & & & & $\begin{array}{l}+32 \\
\text { mesh }\end{array}$ & $\begin{array}{r}\mathrm{m} \ell / \mathrm{g} \\
\quad-32 \\
\text { mesh }\end{array}$ & $\begin{array}{l}+32 \\
\text { mesh }\end{array}$ & $\begin{array}{l}-32 \\
\text { mesh }\end{array}$ & \\
\hline 46.3 & 120 & 11.4 & 10 & 1,000 & 929 & 811 & 149 & 72 & 71.1 & 28.9 & 46.7 \\
\hline 47.3 & 120 & 11.5 & 8.3 & 1,000 & 925 & 805 & 125 & 60 & 70.4 & 29.6 & 51.5 \\
\hline 46.9 & 120 & 10.9 & 6.7 & 1,002 & 917 & 805 & 122 & 51 & 72.2 & 27.8 & 53.9 \\
\hline
\end{tabular}

性炭に含末れている 12〜32mesh 活性炭のメチレンブ ルー脱色力は $149 \mathrm{~m} \ell / \mathrm{g}$ である。乙かし生成活性炭の 中には, メチレンブルー脱色力が $72 \mathrm{~m} \ell / \mathrm{g}$ の $32 \mathrm{mesh}$ 節下活性炭が約 $29 \%$ 含まれ, 賦活収率は全体として $46.7 \%$ である。

怩内滞留時間を 8.3 および $6.7 \mathrm{hr}$ と短くすると, 粒 度範囲 12〜32mesh の生成活性炭のメチレンブルー脱 色力は 125 122ml/g と低くなるが, 32mesh 篩下活 性炭の混合率は炉内滞留時間 $10 \mathrm{hr}$ の場合之あまり変 らなかった。

前田らは，上述のパーム活性炭を使用してFig. 3 に 示すようなジュアルフィルター拉よびトリプルフィル
ターをつくり,たばこ煙のガス蒸気相中の主要成分の 吸着, 複合フィルターの品質なぞについて試験した結 果 ${ }^{435)}$, パーム活性炭はヤシ殼活性炭よりもミクロポフ 一が発達しているため, たばこ煙中のガス蒸気相成分 (アセトアルデヒド, イソプレン, アセトン) の吸着 能がすぐれていることを示した。また，複合フィルタ 一付たばこの香喫味は, 典型的なヤシ殼活性炭フィル ター付たばこのそれと比較して有意差は見られず低二 コチン，低タールたばこ製品用としては，十ン殼活性 炭よりもパーム活性炭がむしろすぐれているという評 価を得た。

これらの研究結果にもとづいて, パーム活性炭がた

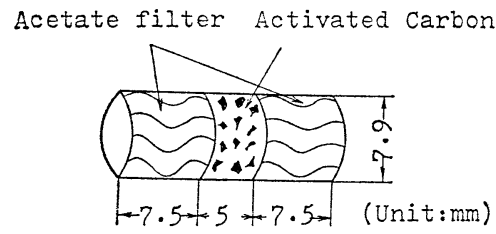

Triple filter

(Palm Activated Carbon : 50mg)
Acetate filter

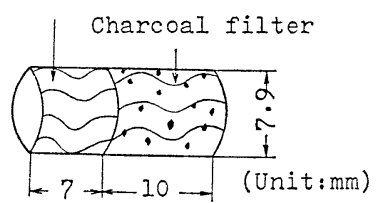

Dual filter

(Coconut Shell Activated Carbon : 43mg)

Fig. 3 Types of charcoal filter

ばこ煙のトリプルフィルター用活性炭として採用され たが，その特性は粒度範囲 16〜32mesh，充て几密度

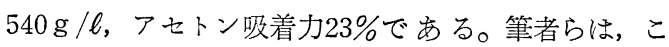
のたばこフィルター用活性炭をFig. 4 亿示す工程で製 造し、メチレンブルー脱色力にて製造管理を実施して いる。

\section{4. 結言}

ヤシ殼炭などの活性炭原料に比較して賦活しにくい パーム炭を出発原料とし，ロータリーキルンを使用し た水蒸気賦活法による粒状活性炭の製造研究を行い, たばこフィルター用活性炭の工業化に成功した。

（1）サイドバーナーと搔上板を付設した直熱式ロ一 タリーキルン（外径 $0.7 \mathrm{~m} \phi \times$ 長さ $12 \mathrm{~m}$ ）により，
粒度範囲 5 ～32meshのパーム炭の水蒸気賦活試験 を実施した結果，生成活性炭のメチンンブルー脱 色力は約 $120 \mathrm{~m} \ell / \mathrm{g}$ と比較的小さかったが, 比較 のために用いたヤシ殼炭をパーム炭より緩やかな 条件で賦活した場合, 生成活性炭のメチレンブル 一脱色力は約 $160 \mathrm{~m} \ell / \mathrm{g}$ であった。

（2）熱風式ロータリーキルン(外径 $1 \mathrm{~m} \phi \times$ 長さ $12 \mathrm{~m}$ ) により, 忓内滞留時間を長くし, さらにパーム炭 の粒度範囲を5〜12，12～32mesh と狭くしてそれ ぞれ賦活試験を実施した結果, 次の条件でメチレ ンブルー脱色力 $150 \sim 180 \mathrm{~m} / / \mathrm{g}$ の活性炭を製造す ることができた。

炉内滞留時間 : $10 \mathrm{hr}$ 


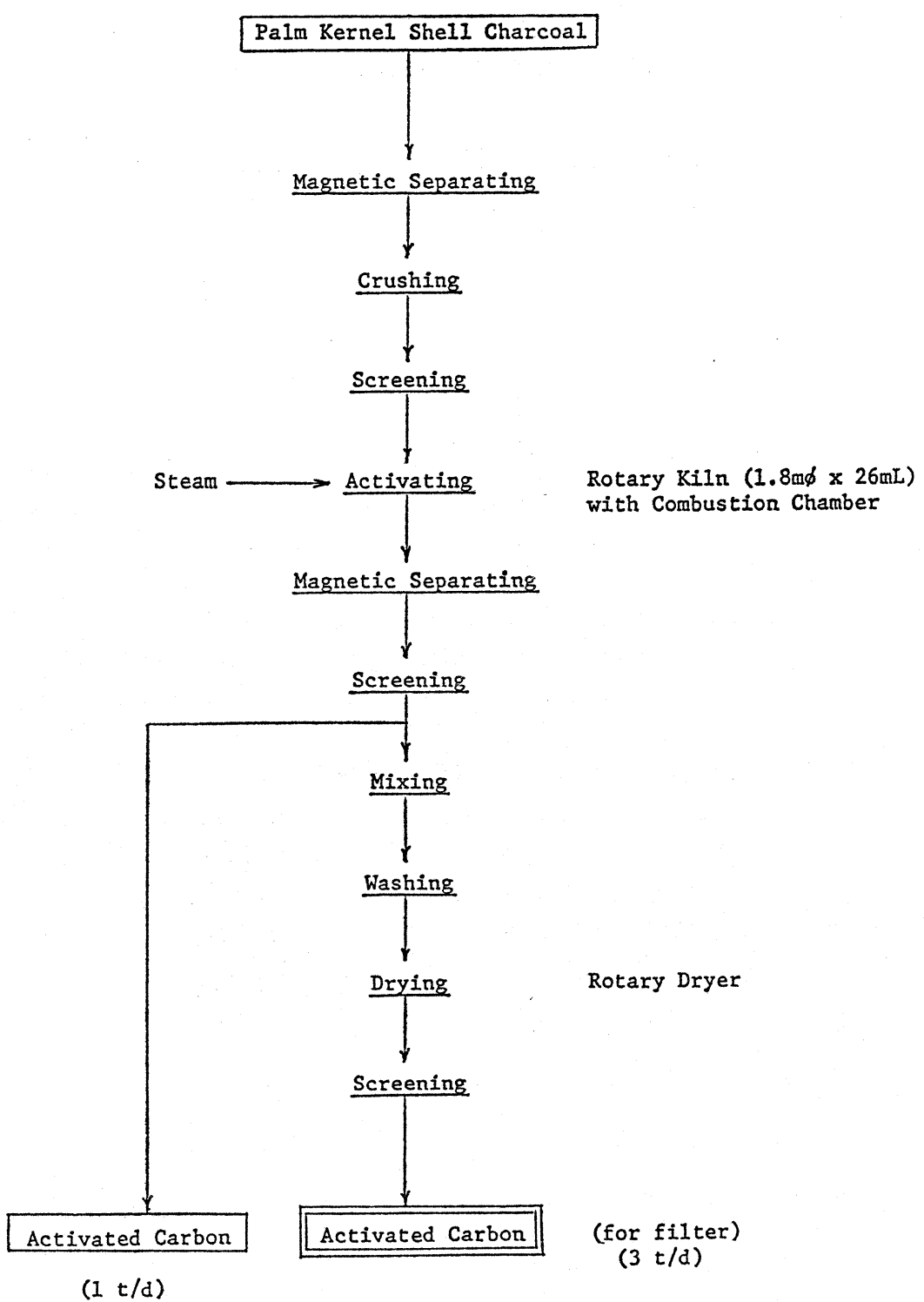

Fig. 4 Manufacturing process of activated carbon

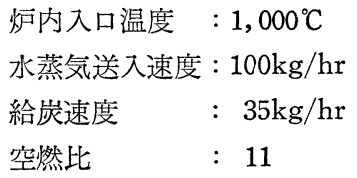

これらの研究結果をもとにして, 熱風式ロータリー キルン（外径 $1.8 \mathrm{~m} \phi \times$ 長さ $26 \mathrm{~m}$ ) によるパーム活性炭 製造プロセスを工業化し，粒度範囲16～32mesh, 充て ん密度 $540 \mathrm{~g} / \ell$, アセトン吸着力 $23 \%$ のたばこフィルタ

一用活性炭を供給している。

文献

1）廣瀬正巳ほか，木材工業，36，329 (1981)

2）廣瀬正巳注か，然協誌，60，780 (1981)

3）廣瀬正巳ほか, 日本化学会誌に投稿中

4）前田和生ほか, 専売中研報, 115，33 (1973)

5）前田和生注か, 専売中研報, 118, 183 (1976) 


\title{
Studies on the Manufacture of Palm Kernel Shell Activated Carbon by Rotary Kiln
}

\author{
Masami Hirose*, Kunio KAWAWAdA* \\ Hiroyuki AOKI*, and Hiroshi YANAI** \\ (*Pacific Metals Co., Ltd., **Nihon University)
}

SYNOPSIS:-Studies were made on the industrial manufacturing process of granular activated carbon from the palm kernel shell charcoal by rotary kiln, and the following results were obtained.

(1) The steam activation test of 5 to 32 mesh palm kernel shell charcoal was performed by an inside fired rotary kiln (0.7m O.D. $\times 12 \mathrm{~m} \mathrm{~L}$ ) equipped with a side burner and scraper boards. It gives only the decoloring power of approx. $120 \mathrm{~m} \ell / \mathrm{g}$ for methylene blue solution.

(2) The steam activation test of palm charcoal grains screened into both 5 to 12 mesh and 12 to 32 mesh, using the rotary kiln with a combustion chamber ( $1 \mathrm{~m} \mathrm{O.D.x} 12 \mathrm{~m}$ $\mathrm{L}$ ) is indicated the following conditions for producing granular activated carbon with methylene blue decoloring power of 150 to $180 \mathrm{~m} \ell / \mathrm{g}$.

Retention time : $10 \mathrm{hrs}$. Kiln inlet temperature $: 1,000^{\circ} \mathrm{C}$

Steam rate $: 100 \mathrm{~kg} / \mathrm{hr}$ Charcoal charging rate $: 35 \mathrm{~kg} / \mathrm{hr}$

Air/Fuel ratio : 11

Based on above results, we industrialized the manufacturing process of palm kernel shell activated carbon by rotary kiln with a combustion chamber (1.8m O.D. $26 \mathrm{~m} \mathrm{~L}$ ) and are now supplying the activated carbon for triple cigarette filter with the following features; grain size $16-32$ mesh, bulk density $540 \mathrm{~g} / \ell$, and adsorption capacity of acetone $23 \%$. 